\title{
Wegener granulomatosisszal (Granulomatosis with polyangiitis GPA) társuló akut ínyhiperplázia (Strawberry Gingivitis)
}

\author{
Irodalmi összefoglaló és esetismertetés
}

\author{
DR. GERA ISTVÁN*, DR. BOGNÁR VERA LILI*, DR. KRISTÓF VERA**, DR. ISTÓK RÓBERT ${ }^{\star \star \star, ~ D R . ~ J A K A B ~ L A ́ S Z L O ́ * * * ~}$
}

\begin{abstract}
A hirtelen kialakuló ínyhiperplázia aggodalomra adhat okot, mivel gyakran malignus vérképzőszervi megbetegedések első tünete, például akut mieloid, monociter vagy limfoid leukémiának. Cikkünk egy 35 éves nő páciens esetét mutatja be, aki két nap alatt kialakult „strawberry gingivitis” tüneteivel jelentkezett 2016 októberében. A különböző hematológiai és immunológiai vizsgálatok azonban kizárták a rosszindulatú vérképzőszervi betegség lehetőségét. Ezt követően helyi érzéstelenítésben hagyományos gingivektómiát végeztünk, majd a teljes eltávolított szövetet hisztológiai vizsgálatra küldtük. A szövettani diagnózis nem specifikus piogén granulóma volt. A beavatkozást követő gyógyulás zavartalan volt, három hét alatt teljes reepithelializáció következett be, recidiva pedig nem alakult ki. Azonban a páciens fizikai állapota tovább romlott és egyre több szerv vált érintetté. Kiegészítő vérvizsgálatok, immunológiai tesztek és egy EBV infekcióra pozitív teszt eredményeként a mononucleosis infectiosa lehetősége merült fel, amely több hétre hátráltatta az adekvát terápia kezdetét. Végül január közepén a klinikai tünetek (strawberry gingivitis, sinus- és fülfertőzés, nyeregorr, tüdőgyulladás, nyálmirigy duzzanat) alapján megszületett a Wegener granulomatosis diagnózisa, melyet az anti-neutrophil citoplazmatikus antitest (c-ANCA teszt) és a submandibularis nyálmirigyből vett pozitív biopszia igazolt. Ekkorra a páciens nagyon súlyos állapotban a Semmelweis Egyetem Belgyógyászati Klinikájára került, ahol masszív kortikoszteroid és immunszuppresszív terápiában részesült. A GPA szokatlanul generalizált formát öltött, a legtöbb szervet és a láb nagy ereit is érintette, az alsó végtag véráramlása megszűnt. Végül a hatékony immunszuppresszív és vazodilatációs terápiának köszönhetően a páciens általános állapota és tüdőérintettsége javult, a láb vérkeringése helyreállt és a nyálmirigyduzzanat megszúnt. Esetünkben többhetes késlekedést okozott a nem specifikus hisztológiai eredmény és a magas anti-EBV és anti-CMV antitest titer, mely felvetette a mononucleosis infectiosa lehetőségét. A GPA gyors progressziója, generalizálódása és potenciálisan halálos volta miatt létfontosságú, hogy a fogorvosok felismerjék a betegség tüneteit és a helyes diagnózis mielőbb megszülessen. Az ínyhiperplázia tehát egy szisztémás betegség első jele lehet, és az időben felállított helyes diagnózis lehetővé teszi az adekvát terápia mielőbbi elkezdését.
\end{abstract}

Kulcsszó: ínyhiperplázia, Wegener granulomatosis, Granulomatosis with Polyangiitis, anti-neutrofil citoplazmatikus antitest

\section{Bevezetés}

A plakk okozta akut vagy krónikus gingivitis egyik tünete a gyulladásos ödéma és sejtes infiltráció miatt kialakult mérsékelt vagy súlyosabb lokalizált vagy generalizált ínymegnagyobbodás. Több páciensnél viszont az ínyduzzanat fokozott gingivális kötőszövet-termeléssel társul, fibrotikus ínyduzzanatot eredményezve. A fibrotikus ínymegnagyobbodás oka lehet pusztán egyéni, genetikai hajlam alapján kifejlődő, gyulladás okozta kötőszöveti túlburjánzás vagy szájlégzés okozta krónikus irritáció, amelynél elsősorban a felső frontfogak érintettek [19]. Sokszor az ínyhiperplázia hátterében szisztémás betegség áll. Egyik gyakori oka a terhesség, ahol a megemelkedett ösztrogén/progeszteron szint következtében a plakk okozta gyulladás kifejezett ödémával, szöveti capilláris állomány felszaporodásával és jelentős sejtes infiltrációval jár [34]. Ennek jellegzetes képe az íny generalizált málnaszerü megvastagodása, vagy a lokális tumorszerú ínyduzzanat, amelyet terhességi epulisnak vagy piogén granulomának nevez az irodalom [19]. A középkorú és ennél idősebb lakosság körében az ínyhiperplázia leggyakoribb formája a gyógyszer okozta ínyelváltozás [40]. Több olyan gyógyszercsalád ismert, amely tartós szedése lassan kialakuló és néha extrém méreteket elérő ínyduzzanatot eredményez. Napjainkban a Ca-csatornablokkoló szerek [29] és a transzplantált betegek által szedett, a szerv kilökődését gátló speciális immunszuppresszív szerek, a cyclosporin származékok társulnak ínyduzzanattal [4].

Az ínymegnagyobbodás oka lehet örökletes, genetikai, ez azonban már fiatal korban a fogváltást követő 
időben manifesztálódik, és klinikai formájában jól elkülönül a többi ínymegnagyobbodás klinikai képétől, amenynyiben a gingiva teljes állománya vastagodik meg, a szövet sejtben szegény, halvány színű és közel porckemény tapintatú [25].

Az eddig tárgyalt ínyduzzanatok lassan, hónapok alatt alakulnak ki. Az ínymegnagyobbodás csupán kis százalékát alkotják az akut módon, néhány nap vagy hét alatt kialakuló generalizált ínyduzzanatok, amelyek nem tévesztendők össze a lokalizált parodontális tályoggal [19]. A hirtelen kifejlődő generalizált ínymegnagyobbodás mindig komoly szisztémás háttérbetegségre utalhat, leggyakrabban malignus hematológiai kórképek gyanúját keltik [56]. Mivel gyakran az akut, akár limfoid, mieloid vagy monociter leukémia egyik korai tünete a hirtelen kifejlődő, sokszor extrém méretű, spontán ínyvérzéssel társuló ínyduzzanat, a páciens elsőnek fogorvoshoz fordul [49]. A fogorvos feladata, hogy felismerje a bajt és haladéktalanul a páciens belgyógyászati és hematológiai kivizsgálását kezdeményezze. Klinikai statisztikák szerint az akut leukémia 10-60\%-ban társul ínyhiperpláziával. Egy USA-beli közlemény szerint 1076 akut mieloblasztos leukémiás pácienst vizsgálva 66,7\%-ban találtak ínyduzzanatot [12]. Akut mielomonocitás leukémiában az incidencia (18,5\%) volt, és akut mielocitás leukémiában ritkábban fordul elő ínyduzzanat (3,7\%) [7]. Krónikus leukémia is társulhat, bár ritkábban, masszív ínyhiperpláziával, azonban az lassan fejlődik ki és többnyire a fogorvoshoz érkező páciens már tudatában van betegségének [19].

Bizonyos gasztrointesztinális kórképekkel, elsősorban a Crohn betegséggel, vagy colitis ulcerosával is társulhat ínyduzzanat, amely az ún. piostomatitis vegetans tünetcsoport egyik része, amelyben az íny megduzzad és milliáris pusztulák alakulnak ki a gingiva propriában. Klinikai képe jellegzetes, a laza szerkezetű vörös színű ínyszövet felszínét sok, gombostűfejnyi pusztula borítja [32].

Igen ritkán találkozunk olyan akut generalizált ínymegnagyobbodással, ahol a hagyományos rutin hematológiai vagy immunológiai kivizsgálás sem vezet korai diagnózishoz. Egy korábbi cikkünkben beszámoltunk egy fiatal nő esetéről, aki anamnézisében három éve fennálló trombocitopénia miatt nagyon sokszor, néha

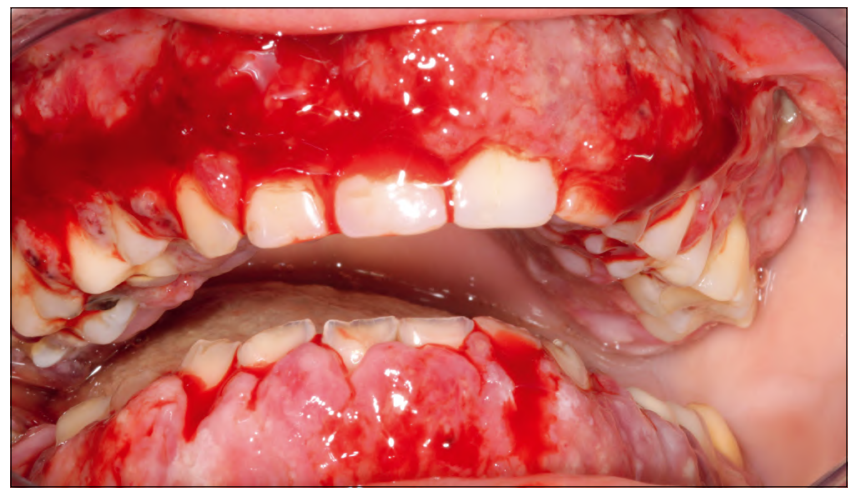

havonta kapott vért vagy vérkészítményeket [9]. Az extrém méretű ínyduzzanata néhány nap alatt fejlődött ki. Az elsődleges szövettani lelet nem specifikus piogén granulomát igazolt. A mind a két állcsontot elborító, spontán vérző szövetszaporulatot altatásban, hagyományos gingivectómiával a perioszteum szintjéig távolítottuk el, amely szépen gyógyult, de néhány nap múlva folyamatosan recidivált (1. ábra $a, b)$. Végül a hematológussal történt konzultációt követően, szisztémás kortikoszteroid kezelést kezdtek el (32 mg Medrol/nap). A szteroid kezelés 7 . napján a recidivált duzzanat teljesen eltűnt, panaszai megszűntek [9]. Azonban a páciens továbbra is kortikoszteroid kezelés alatt állt, és csak így maradt tünetmentes. A beteg hematológiai betegsége és anamnézise, valamint a rendelkezésre álló irodalmi adatok alapján a feltételezett diagnózisunk a politranszfundált betegben kialakult autoimmun vasculitis volt, aminek hátterében feltételeztük a graft versus host reakciót [9, 38, 41, 50].

Az immunvasculitisekhez társuló ínyhiperplázia ritka, de ha előfordul, nagyon jellegzetes klinikai képet ad, amely ilyenkor segít a súlyos háttérbetegség korai diagnosztikájában [6, 14, 39, 50].

$\mathrm{Az}$ antineutrofil citoplazmatikus antitesthez (ANCA) köthető autoimmun vasculitisek csoportjához több, hasonló patogenezisű ritka kórkép tartozik. Ide sorolható az antineutrophil citoplasmic antibody associated vasculitides (AAV), microscopic polyangiitis (MPA), az eosinophil granulomatosis with polyangiitis (EGPA), valamint a granulomatosis with polyangiitis (GPA), szerzői nevén a Wegener gramulomatosis [8]. A kórképet patológiai esetek feldolgozása után Wegener írta le 1939-ben [54, 55]. Pontos etiológiája és patomechanizmusa még ma sem tisztázott, de az tény, hogy immunvasculitisek közé sorolt, nekrotizáló, granulomatosus kisérgyulladás [8, $10,18,42]$. A Wegener granuomatozis, amelyet az utóbbi időkben az angolszász irodalom „Granulomatosis with polyangiitis" (GPA) diagnózissal illet, nagyon ritka betegség. Európában a GPA prevalenciája 1-9 /millió lakos között mozog [17, 36, 42, 53], a többi előbb felsorolt immun vasculitisek még ritkábbak [18]. Egy magyarországi statisztika szerint az Országos Korányi Pulmonológiai Intézetben harminc év alatt 15 Wegener granulomatózisban szenvedő esetet diagnosztizáltak [10].

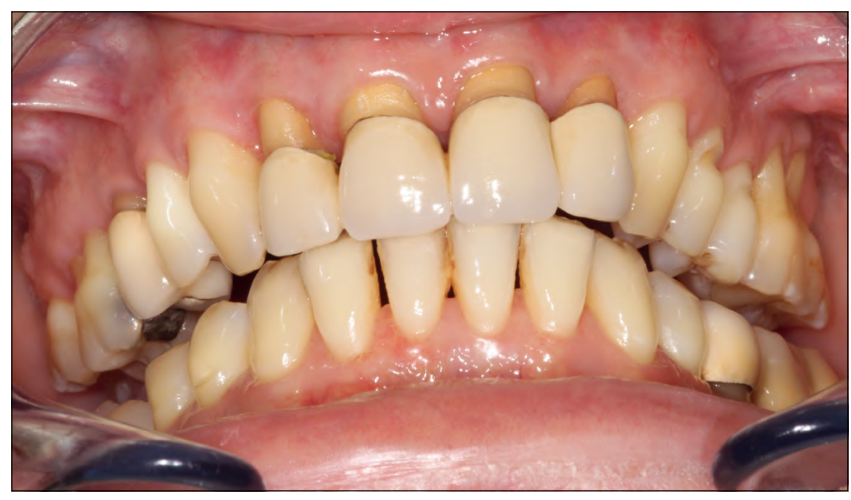

1. ábra a), b) Az öt évvel korábban észlelt immunvasculitiszes betegünk kiindulási és a kezelés utáni képe 
A GPA patogenezise nem pontosan tisztázott, valószínűsíthető, hogy bakteriális vagy vírusinfekció aktiválja a folyamatot, de több bizonyíték szól amellett is, hogy bizonyos örökletes genetikai hajlam vagy a gyulladásos citokineket kódoló gének polimorfizmusa hajlamosíthat e ritka betegségre [18, 37]. A GPA mindenképpen egy B-sejt mediált humorális immunreakció, amely nagy mennyiségben pro-inflammatorikus citokin expresszióhoz vezet (TNF- $\alpha$ és IFN- $\gamma$ ), amely azután az aktiválódott PMN leukociták felszínén speciális felszíni antigének expresszálódását váltja ki. Ugyanakkor a petogenezisben érintett a celluláris immunrendszer és a komplement rendszer is [18]. Az autoantigének egyike a szerin-protenináz 3 , az ún. antineutrofil citoplazmatikus antigén (ANCA), amely az antineutrofil citoplazmatikus antitestek (c-ANCA) target antigénje. A másik a PMN leukociták és monociták mielperoxidáz enzime (MPO) ellen irányuló antitestek, a p-ANKA target antigénje. Ez a komplex 2-/3-as típusú immunreakció a PMN leukociták degranulációjához vezet, nagy menynyiségben szabadítva fel mátrix metalloproteináz enzimeket, valamint reaktív oxigéngyököket, amelyek a kiserek endothel sejtjeinek pusztulását okozzák, s ez végül a környező szövetek pusztulásához és krónikus gyulladásos granulomatózus szövetszaporulathoz vezet $[10,18,26,27,45]$.

A GPA-nak újabban két típusát különítik el, az egyik a klasszikus, generalizált forma, amely régen halálos betegség volt. Ennek jellegzetes tünetegyüttese: nekrotizáló, granulomatosus érgyulladás a felső és alsó légutakban, valamint a vesékben zajló autoimmun glomeruonephritis, valamint súlyos neurológiai panaszok. A lokalizált forma klinikai tünetei is változatosak, alapvetően a felső légutakat, az arctájékot érinti, és prognózisa jobb [5]. A szájtünetek viszonylag gyakran fordulnak elő, irodalmi adatok szerint a szájüreg érintettsége $10-62 \%$ között mozog $[42,50]$. Gyakori orális tünete a nem specifikus szájnyálkahártya erózió, vagy aphtha szerü ulceráció, de előfordul faciális parézis is [16, 33]. Ritkán társulhat vele súlyos ínymegnagyobbodás, annak egy jellegzetes, lágy, livid, eperszerú gingiva hiperplázia formája, amelyet az angolszász irodalom „strawberry gingivitis" névvel írt le [6, 14, 39, 50]. Klinikailag a gingiva diffúzan duzzadt, sötétvörös színű és apró, pusztulaszerủ hólyagocskák és mikro bevérzések borítják. Az irodalomban több esettanulmányt találhatunk, melyek rámutatnak arra, hogy a "strawberry gingivitis” sokszor a GPA első klinikai jele lehet [2, 6, 14, 24, 35, $39,47,50,51,52]$. Mivel a jellegzetes „hyperplasticus strawberry gingivitis" a Wegener granulomatosis egyik korai tünete és ezzel a beteg elsőnek fogorvoshoz/szájsebészhez fordulhat, fontos, hogy a fogorvos ismerje e kórképet, mert ezzel segíthet e potenciálisan letális kimenetű betegség korai felismerésében, pontos klinikai diagnosztikájában és az időben elkezdett adekvát kezelésben.

Nincsenek specifikus laboratóriumi eltérések, leírtak fokozott vörösvértest süllyedést, jelentősen megemel- kedet akut fázisfehérje (CRP)-szintet, leukocitózist és ezzel társuló relatív és abszolút limfopéniát, mérsékelt anémiát, hématúriát, cilindrúriát, és proteinuriát [18].

A klinikai tünetek és rutin laboratóriumi leletek mellett pontos diagnosztikus értékkel a keringő, magas specificitású antineutrofil citoplazmatikus autoantitestek (c-ANCA) kimutatásának van döntő jelentősége [33, 48]. Ugyanakkor az érintett szerv szövettani vizsgálatával specifikus immunofluorescens technikával kimutatható a fehérvérsejtekben, a citoplazmában az ANCA jelenléte. A legtöbb ANCA vasculitisben a betegből vett biopsziás lelet, vagy a perinukleáris ( $p$-ANCA) vagy a citoplazmatikus (c-ANCA) antitesttel ad pozitív reakciót. A GPA-ban elsősorban a c-ANCA a citplazmában lévő cisteinproteinaz-3 ellen termelődik, míg egyéb immunvasculitisben a p-ANCA a PMN leukocita és monocita primer (azurofil) granulumaiban raktározott mieloperoxidáz (MOP) enzim ellen irányul. GPA betegségben tipikus a szövettani c-ANCA pozitív szövettani lelet $[1,18$, 48]. A rutin HE festés mellett a szövettani lelet sok esetben nem specifikus, mert elsősorban a felső légutakban és a szájüregben zajló másodlagos gyulladás módosítja a jellegzetes szövettani képet, és az innen vett biopsziás anyag nem mindig patognosztikus. A bőrben zajló angiitis szövettanilag aspecifikus, úgynevezett leukocytoclasticus angiitis, így a biopsziának nem túl nagy a diagnosztikus értéke [18].

Kezelése tüneti. Korábban a betegség halálos volt, veseelégtelenség vagy súlyos tüdőkárosodás miatt légzési elégtelenségben haltak meg a betegek $[1,18]$. Ma az immunszuppresszív kezeléssel a tünetek javíthatók és hosszas kezelés után remissziók érhetők el. A szuverén gyógyszere a kortikoszteroid és a ciklofoszfamid. Idővel a tünetek újra fellángolhatnak, ezért nagyon fontos a betegek folyamatos monitorozása és a fenntartó terápia pontos beállítása [18, 21].

\section{Esetismertetés}

A következőkben a korábban közölt [9] esetünkhöz sokban hasonló páciensről számolunk be, akinél napok alatt fejlődött ki extrém méretű generalizált, pusztulózus ínyhiperplázia, és amelynek a kivizsgálása és a feltételezett okok kiderítése közel kéthónapos hematológiai, virológiai és immunológiai kivizsgálást igényelt, amely végül elvezetett a GPA klinikai diagnózisához és az adekvát terápiához.

Páciensünk, egy 35 éves nőbeteg 2016. október 12én jelentkezett a Semmelweis Egyetem Parodontológiai Klinika ambulanciáján. A páciens fő panasza, hogy két nappal korábban a felső ínye, esősorban a két szemfoga között hirtelen jelentős mértékben megduzzadt, fájdalmas lett, az ínyből rossz szagú gennyes váladék szivárgott. Nagyon rossz közérzete volt, és a nyaki nyirokcsomók is megduzzadtak. Általános állapotát illetően napok óta nagyon elesett, gyenge volt, nem tudott aludni, hőemelkedése volt. Erős fejfájás kínozta és a 

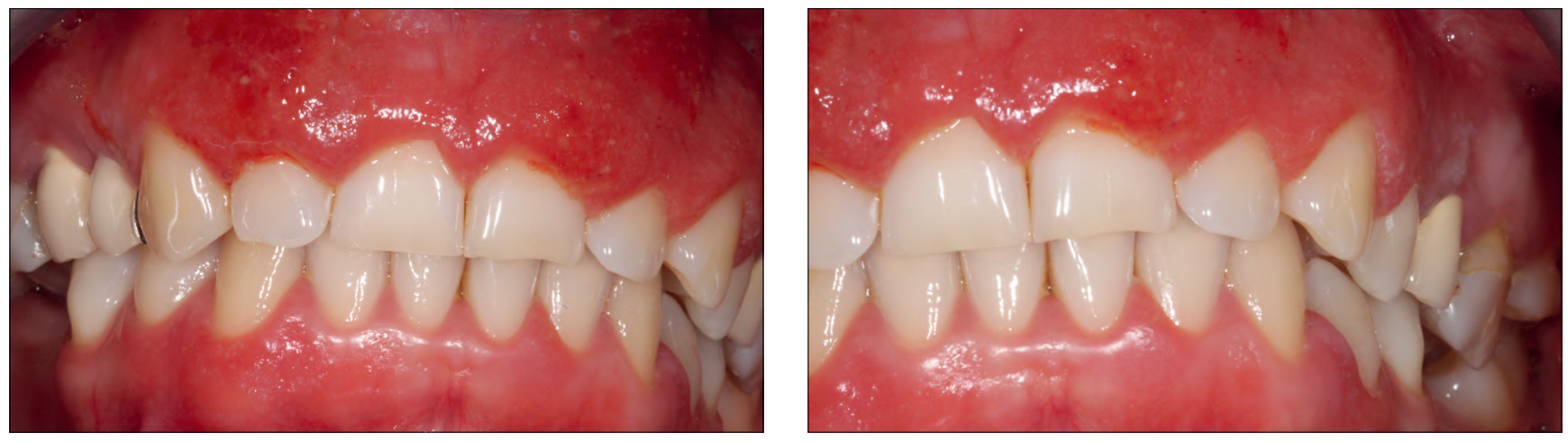

2. ábra a), b) A páciens jelentkezésekor észlelt, a felső front és premoláris fogak területére lokalizálódó fellazult szerkezű livid színű, apró, tűszúrásnyi sárgás sipolyokkal borított ínyduzzanata

fejbőrén furcsa bizsergő érzése volt, olyan, mintha bogarak szaladgáltak volna a hajában. Az orra eldugult, mindkét oldali arctájon nyomásra fájdalmat érzett. A végtagjai is fájtak és nagyon erőtlenek voltak.

Anamnézisében komolyabb szisztémás betegség nem szerepelt. Két gyermek anyja, az egyik 12, a másik 15 éves. Mindkét terhessége zavartalan volt, a terhesség kapcsán nem tapasztalt súlyos ínygyulladást vagy ínyduzzanatot. Korábban csak ritkán volt beteg, amely többnyire a szokásos légúti betegség volt. Korábban gyógyszert nem szedett. Fogorvoshoz rendszeresen járt, de nem voltak különösebb fogászati panaszai, tud néhány letörött vagy szuvas fogáról, azonban az elmúlt hónapokban nem volt fogorvosnál. Most azonban azonnal felkereste a körzeti fogorvosát, aki a Parodontológiai Klinikára utalta.

Felvételkor a fiatal, közepesen fejlett és táplált nő extraorális vizsgálatakor duzzadt, nyomásra érzékeny submandibularis nyirokcsomókat tapintottunk, láztalan volt, az arcon egyéb kóros eltérést nem észleltünk. Intraorális vizsgálat során a felső fogsor mentén a gingiva propria a premolárisok közötti területen duzzadt, fellazult szerkezű, ödémás, livid színű, melynek felszínén milliáris, apró, tűszúrásnyi sárgás sipolyok voltak láthatók, amelyekből enyhe nyomásra híg, sárgás váladék ürült (2. ábra $a, b)$. A duzzadt ínyszél vonala helyenként több milliméterrel a zománc-cement-határtól koronálisabban húzódott. Szondázáskor a parodontális szonda ellenállás nélkül hatolt az ínyszél alatt az orralapig. Palatinálisan a gingiva nem mutatott kóros elváltozást, szorosan tapadt a fognyakon, tasak nem volt szondázható. A moláris régióban az íny állapota nem mutatott kóros eltérést, szondázáskor helyenként a gingiva pozitív BOP értéket produkált, de a PPD értékek 1-3 mm között mozogtak. Az alsó fogsor mentén a gingiva teljesen ép, nem mutatott gyulladásos jeleket. Az OP felvételen a felső moláris régióban több carieses fogat észleltünk, valamint inkomplett gyökértöméssel ellátott moláris fogakat elörehaladott periapicalis léziókkal [26, 27, 28, 48]. Az 14, 38, 36, 46, 47 fogak hiányoznak (3. ábra). Ugyanakkor a röntgenfelvétel szerint a felső frontfogak körül az alveoláris csont-

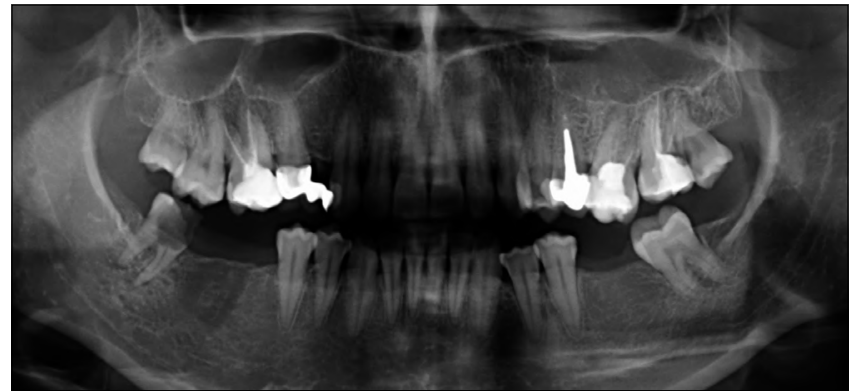

3. ábra: A páciens felvételekor készült OP felvételén a front régióban nem látszik jelentős approximális tapadásveszteség.

állomány megtartott, periapikális csontléziók ellenére interproximális csontpusztulással járó parodontális betegség nem volt diagnosztizálható.

A nagyon laza szerkezetű, livid színú ínyduzzanat és a rapid kialakulás miatt elsődleges feltételezett diagnózisunk hematológiai vagy immunológiai szisztémás állapothoz társuló gingivahiperplázia volt. Ennek értelmében a pácienst azonnal sürgösségi belgyógyászati kivizsgálásra és laboratóriumi vizsgálatra küldtük akut leukémia-irány diagnózissal. A még aznap elvégzett vérképvizsgálat kizárta a malignus vérképzőrendszeri betegség gyanúját, ugyanakkor a laboreredmények igen magas CRP-értéket $93,5 \mathrm{mg} / \mathrm{l}$ (normál 0-5 mg/l) és mérsékelten emelkedett fehérvérsejtszámot $14,8 \mathrm{~g} / \mathrm{l}$ (normál érték 4-9 g/l) mutattak. A következő napon a gingiva még duzzadtabb lett (4. ábra a). Ekkor helyi érzéstelenítésben és antibiotikus védelemben $(2 \mathrm{~g}$ Clavunált Amoxycillin egy órával mútét előtt) subgingivális óvatos kürettálást végeztünk és két, viszonylag jobban megtartott ínypapillából biopsziás mintát vettünk szövettani vizsgálat céljából (4. ábra b). A sebet 06 monofil fonallal zártuk. A páciensnek naponta $2 \times 1$ tabletta Augmentin duo szedését rendeltük és további hematológiai kivizsgálást kértünk. Két nap múlva a páciens általános állapota tovább romlott, az ínyduzzanat súlyosbodott és nyomásra a felszínéből még erősebb véres, sárgás váladék ürült (5. ábra a). Az ismételten elvégzett laboratóriumi vizsgálati eredmények több paraméterben igen 

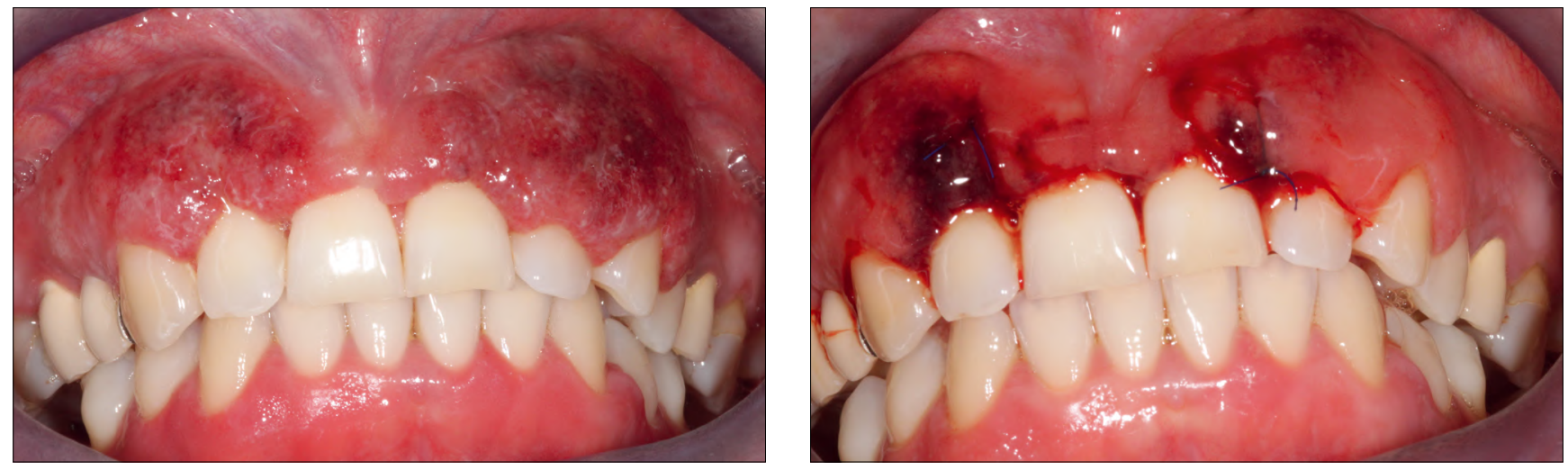

4. ábra: A gingivából az 5. napon biopsziás mintavétel
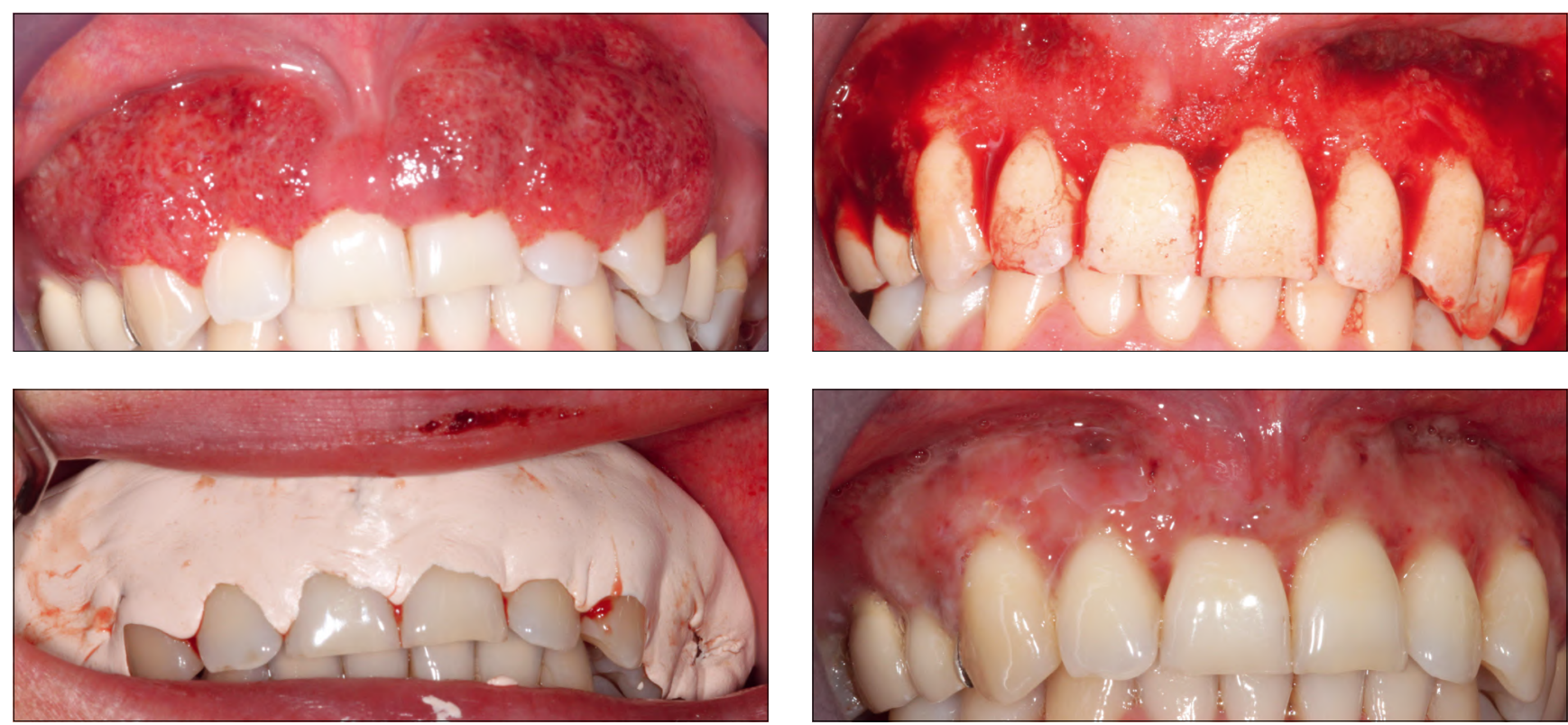

5. ábra: A hiperplasiás ínytömeg eltávolítása rádiófrekvenciás rádiósebészeti szikével: a) az íny állapota mútét előtt, $b$ ) közvetlenül mútét után, c) parodontális sebvédő pakolás a seben (CoePack), d) egy nappal a mútét után, a sebvédő pakolás eltávolítása után.

jelentős romlást mutattak (FVS 10,7 g/l, neutrofil $86,6 \%$, limfocita $9,9 \%$, monocita 3,5\%, süllyedés $75 \mathrm{~mm} / \mathrm{h}$, CRP 99,6 mg/l). Mivel a szérum-fehérjeértékek igen magas eredményt adtak (összefehérje 92,2 g/l, GOT91 U/l, GPT $283 \mathrm{U} / \mathrm{l})$, mely az immunológus szerint lehetett az Augmentin mellékhatása is, ezért az Augmentinről $3 \times$ $300 \mathrm{mg}$ clindamycin (DalacinC) alkalmazásra tértünk át. A páciensünknek, okulva korábbi esetünkön, ahol a kortikoszteroid alkalmazása gyors javulást eredményezett, mi ekkor naponta $32 \mathrm{mg}$ Medrolt rendeltünk. Bár ennek hatására általános állapota kicsit javult, de négynapos szedés után az őt vizsgáló immunológus ezt leállította, mivel még korántsem volt biztos a gyulladás okában és nem volt kizárható a mikrobiális ok. A beteg parodontális állapotát naponta ellenőriztük. Általános és parodontális állapota tovább romlott, az ínyduzzanat pedig jelentős mértékben fokozódott (5. ábra a).

A felvételt követö 10. napon megérkezett a biopsziás szövettani lelet, amely nem specifikus diffúz ínygyulladás képét mutatta, malignus vérképzőrendszeri betegségre vagy tumorra utaló szövettani elváltozást azonban nem igazoltak, a szövettani diagnózis: acut pyogen granulóma volt. A biopsziás eredmény birtokában már vállalkoztunk invazívabb mútéti beavatkozásra, és így a felső frontfogak területén helyi érzéstelenítésben még aznap magas-frekvenciás rádiósebészeti műszerrel, a hiperplasztikus ínyszövetet premoláristól premolárisig eltávolítottuk (5. ábra $b, c, d$ ). A mütét során derült ki, hogy a gingiva tunica propria tejesen ép volt és a perioszteum szorosan tapadt az alveoláris csonton és lényegében az egész folyamat csupán a gingiva propria hámjában és a közvetlen alatta húzódó kötőszövetben zajlott (5. ábra $b$ ). Tehát valódi tasakképződésről nem volt szó, annak ellenére, hogy még preoperatívan is több mint $15 \mathrm{~mm}$ szondázási mélységet mértük, és a parodontális szonda ellenállás nélkül hatolt be apicalisan 
a mucogingivális határvonalon túl. Látva a tunica propria megtartott állapotát, a maradék granulációs szövetet Gracey kürettel távolítottuk el, minimális vérzés kíséretében (5. ábra b). A sebre parodontális sebvédő pakolást helyeztünk (CoePak) (5. ábra c). Postoperatívan a páciensnek chlorhexidines szájöblítést és szükség esetén Cataflam $V$ fájdalomcsillapítót rendeltünk. Egy nappal később, október 25-én a parodontális pakolóanyagot eltávolítottuk, hogy ellenőrizzük a gyógyulást. A gingiva propria gyógyulása már egy nap után megnyugtatónak tünt (5. ábra d).

Közben tovább folyt a páciens hematológiai-immunológiai kivizsgálása, vérképét hetente kétszer ellenőrizték, és állandó kapcsolatot tartottunk fent a beteg orvosaival. Az újabb laboratóriumi vizsgálat szerint a páciens szérumfehérje értékei normalizálódtak, feltehetően az Augmentin elhagyása miatt, ugyanakkor vesefunkciós értékei romlottak, enyhén hiperglikémiás lett, a még mindig magas CRP 44,9 mg/l mellett, a leukocitózist továbbra is relatív limfopénia és a PMN leukocita magas aránya 83,9\% jellemezte. A még októberben a gingivális lézióból vett bakteriológiai leoltás nem mutatott ki specifikus baktériumtörzset. Az október 27-i laboratóriumi eredmények további javulást mutattak, a CRP $7,6 \mathrm{mg} / \mathrm{l}$ értékre, a vérsejtsüllyedés $29 \mathrm{~mm} / \mathrm{h}$ értékre csökkent, továbbra is emelkedett fehérvérsejtszám mel-

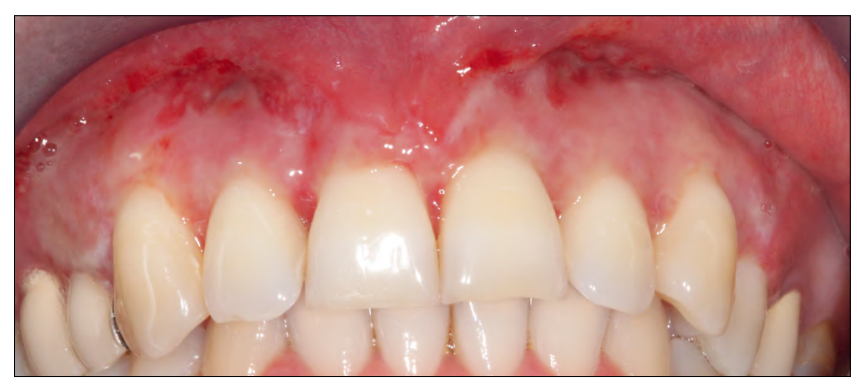

6. ábra: A per secundam sebgyógyulás és az íny kezdődő epithelializációja
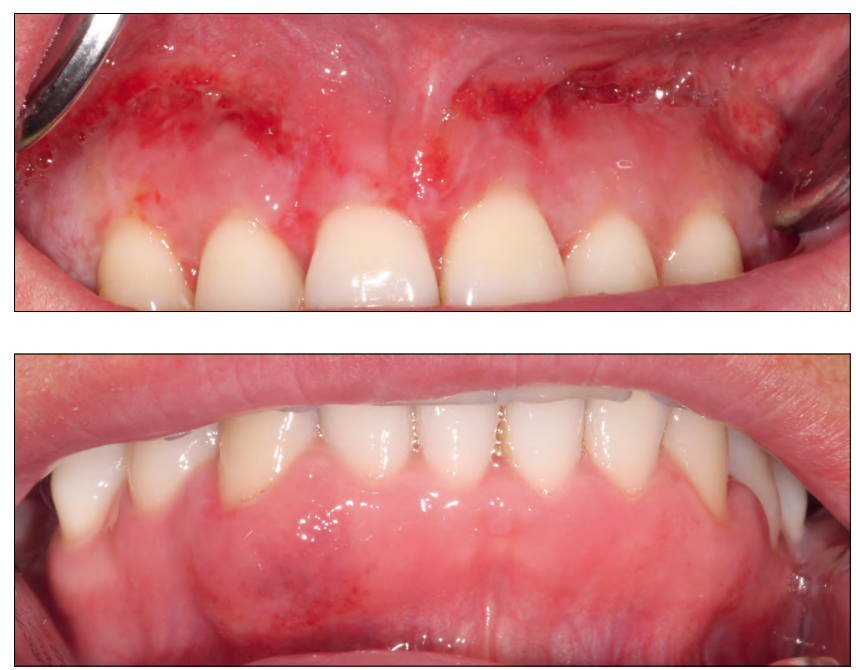

7. ábra: A gyógyuló maxilláris régió mellett az addig ép jobb oldali szemfog régióban lokalizált laza szerkezetú livid ínyduzzanat
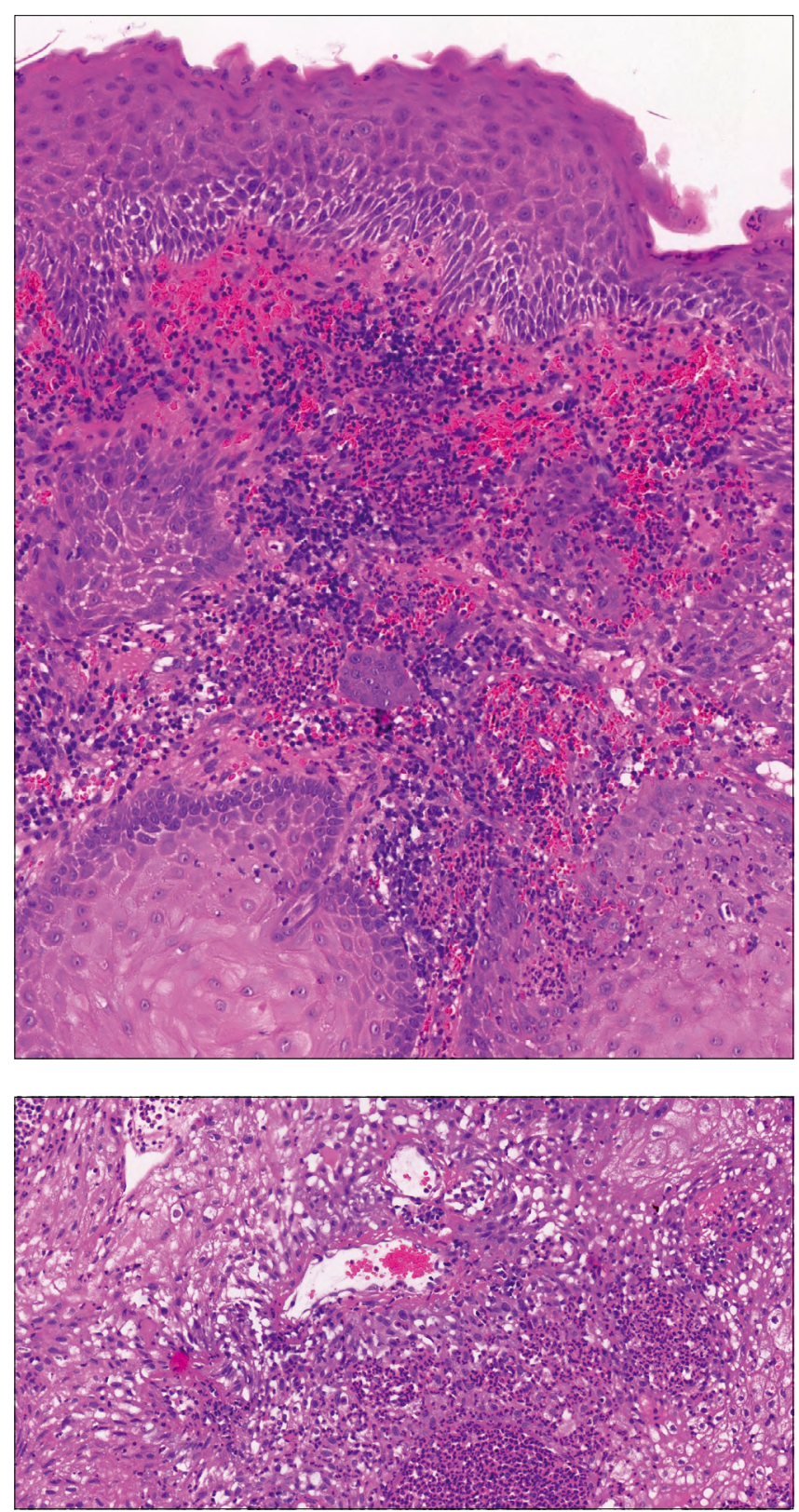

8. ábra: A második in totó eltávolított szövet szövettani eredménye: a gingivát masszívan infiltrált hám borítja, kitöltve granulocitákkal, a mélyebb rétegekben pedig abscessusszerü beolvadt területeket láthatók. Szövettani diagnózis: gingivitis acuta abscedens

lett. Közben a mútét után 10 nappal a gingiva sebfelszín kezdett behámosodni és megkezdődött a gingiva propria keratinizációja, amelyet 1\%-os ZnCL2 adsztringens ecseteléssel is elősegítettünk [19] (6. ábra a). Ugyanakkor az addig ép jobb oldali front régióban laza szerkezetú ínyduzzanat alakult ki (7. ábra $a, b)$. Megérkezett a második szövettani lelet, most már a teljes eltávolított ínyszövetet értékelve, továbbra sem állapítottak meg specifikus eltérést és a következő leírást adták: a metszetekben látható gingiva részleteket maszszívan infiltrált hám borítja, kitöltve granulocitákkal, a mélyebb rétegekben pedig abscessusszerü beolvadt területek láthatók. Szövettani diagnózis: gingivitis acuta 
abscedens (8. ábra $a, b)$ ). A mütét után két héttel a felső frontrégióban a gingiva propria behámosodott, a jobb alsó szemfog körüli ínyduzzanat spontán visszafejlődött. A páciens szuper puha fogkefével már tudott fogat mosni, azonban általános rossz közérzete nem javult és a jobb alsó szemfog környékén a gingiva minimális mértékben ismételten megduzzadt és vörhenyes színüvé vált (9. ábra $a, b)$. A beteget kétnaponta ellenőriztük és figyeltük a felső gingiva sebgyógyulását és az alsó ínyduzzanat alakulását. November 24. és december 8. közötti időben a gingiva hámja teljesen megerősödött, a keratinizáció befejeződött, amit napi kétszeri 1\%-os cinkklorid oldatos ecseteléssel is siettettük (9. ábra a, $b, c, d)$. A november 21-i laboratóriumi leletei sem mutatnak további javulást. A fehérvérsejtszám $11,23 \mathrm{~g} / \mathrm{l}$, a neturofil arány $80 \%$, a limfocita $11 \%$. a vérsejtsüllyedés $33 \mathrm{~mm} / \mathrm{h}$ és a CRP megint emelkedett $22,9 \mathrm{mg} / \mathrm{l}$.

Bár december közepére a gingiva teljesen gyógyult, ugyanakkor általános állapota tovább romlott és új, addig nem észlelt tünetek jelentek meg. Továbbra is duzzadtak voltak a regionális nyirokcsomói, de már mindkét oldali arcürege fájt, az orra eldugult, és az orrnyergen szimmetrikus tömött tapintatú duzzanat jelent meg. Teljes arcmimikája megváltozott, az arcbőre kifeszült. Közben az immunológus és infektológus által elrendelt $v i$ rológiai vizsgálat magas anti-CMV IgG szintet mutatott ki (51 UA/ml ELFA), amely az immunológusok szerint lezajlott primer CMV infekcióra utal, és az EBV elleni antitest titere is igen magas volt (EBNA IgG, IgM ELISA
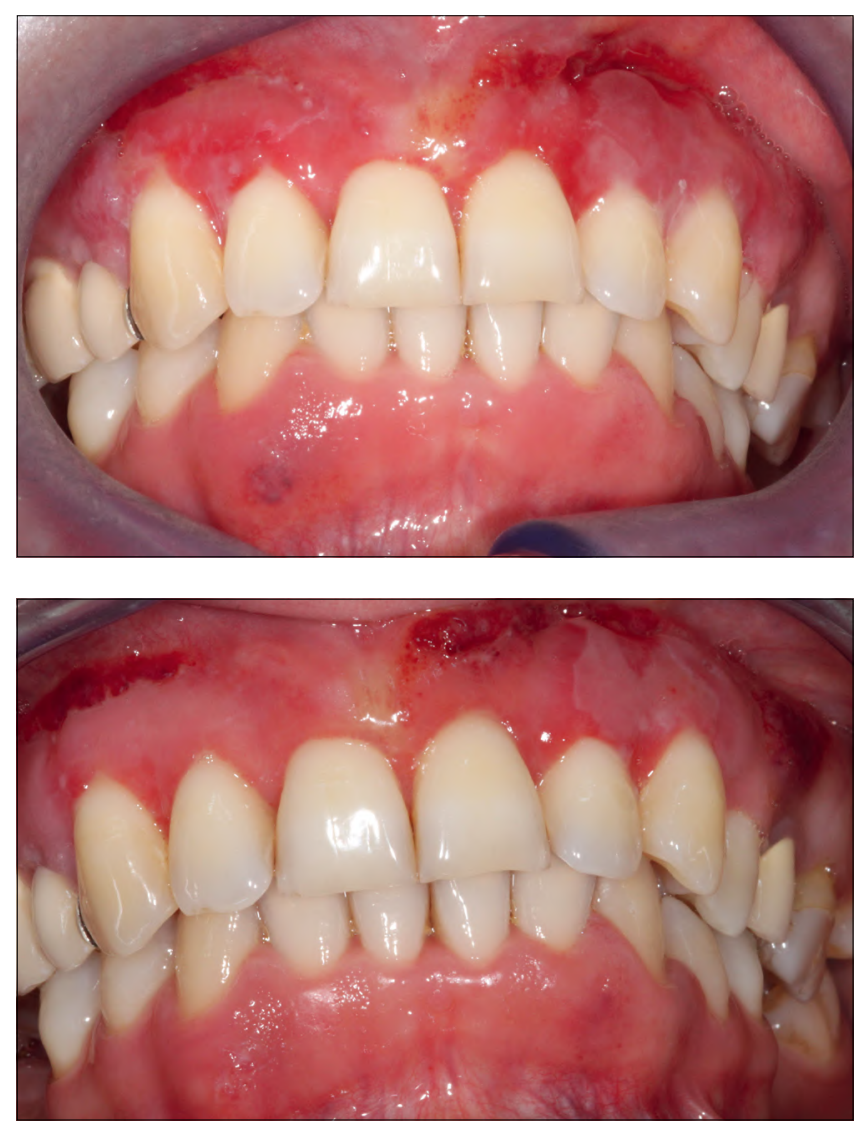

pozitív). A vírus elleni magas antitest titer eredmények a CMV-EBV okozta mononucleosis infectiosa diagnózist valószínúsítették, amely súlyos akut abscedáló gingivahiperpláziával társulhatott.

December 22-i és a 2017. január 19-i klinikai vizsgálat szerint a gingiva teljesen gyógyult, a páciens jó szájhigiéniát tudott fenntartani, és minden orális panasza megszünt (10. ábra $a, b$ ). Ugyanakkor január elején mellkasröntgen alapján kétoldali pneumoniát diagnosztizáltak a betegnél, melyre lakóhelyén 4 alkalommal kapott Rocephin injectiót intramuscularisan. Az újabb immunológiai vizsgálat szerint az immunpanel negatív volt (HIV-negatív, CMV IgM neg, IgG poz, EBV IgM neg, IgG poz).

A felvételt követö 60. napon (január 10.) körül a submandibularis és sublingualis nyálmirigyek megduzzadtak, az egész szájfenék deszkakemény lett, a betegnek komoly nyelési és szájnyitási akadályt okozva (11. ábra). A nyálmirigyduzzanat még mindig magyarázható lett volna a CMV-EBV infekcióval, de január második hetében olyan, elsősorban az alsó végtagokra lokalizálódó panaszai alakultak ki, amely miatt járni alig tudott, teljesen erőtlen volt és nagy fájdalmai voltak. Ekkor jelent meg ismételten a Parodontológiai Klinikán kontroll vizsgálatra. Ekkor a 48 fog körül akut periapicalis periodontitis alakult ki, ami miatt ez a fog eltávolításra került. Parodontálisan teljesen rendben volt, azonban a beteget nagymértékben romlott általános állapota és végtagpanaszai miatt január 19-én sürgősséggel be-
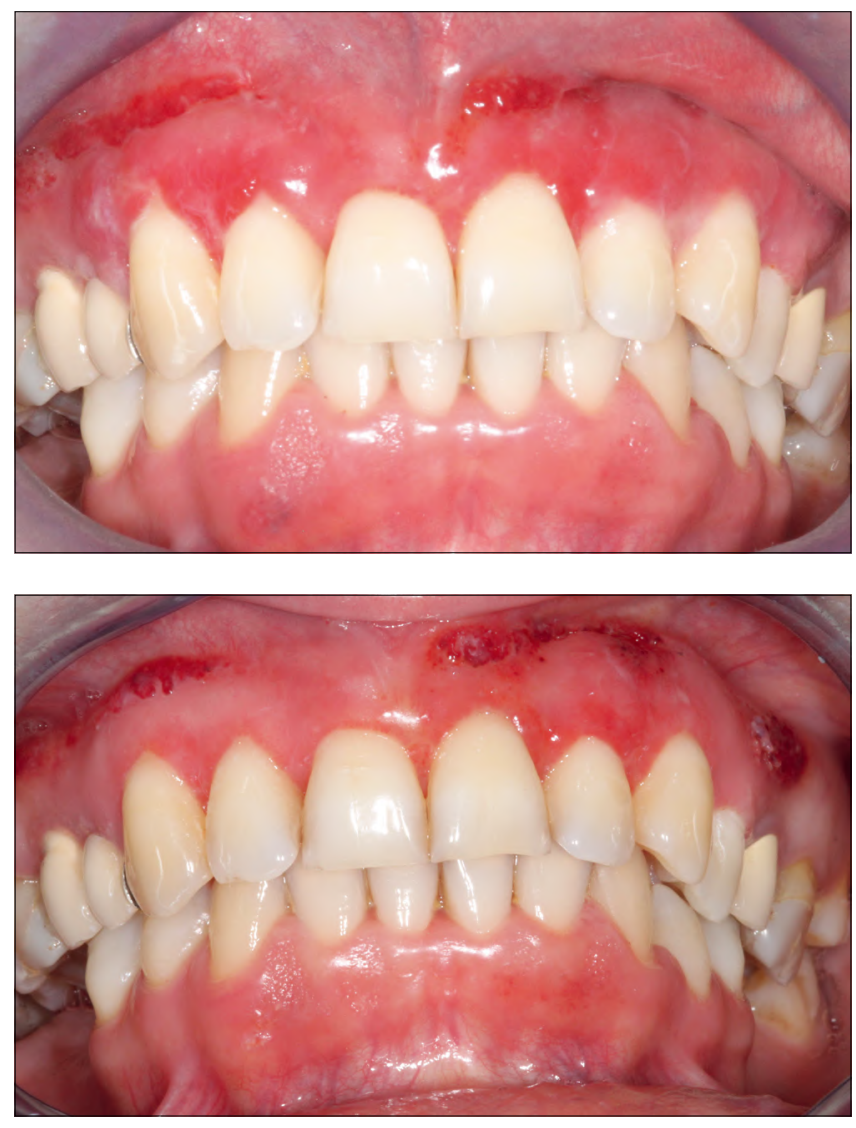

9. ábra: A gingiva állapotának változása november közepe és december eleje között 


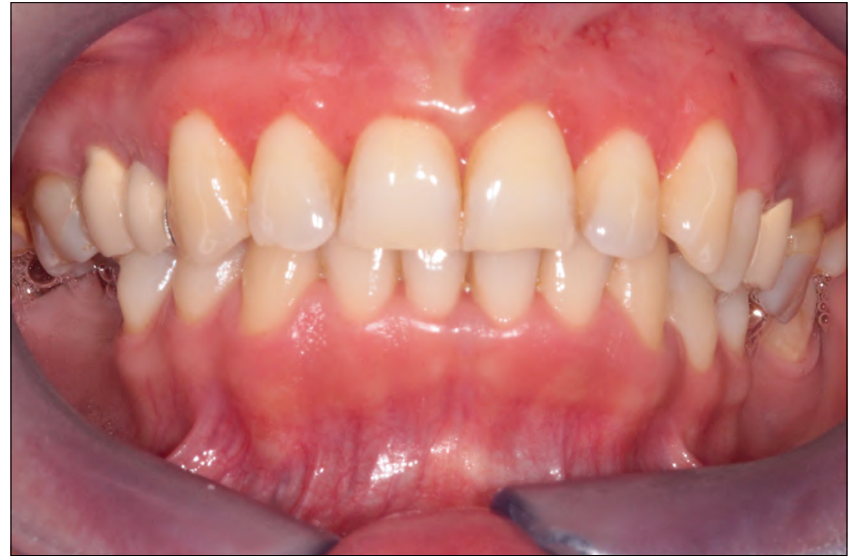

10. ábra: December végére az íny közel teljesen begyógyult és újabb recidíva nem alakult ki.

utaltuk a SE III. sz. Belgyógyászati Klinika Immonológiai osztályára. Felvételkor elvégzett laboratóriumi vizsgálatok eredménye: Fvs. 12000, Sü: 83 mm/h Kreatinin 52 umol/l, CRP: 125-165 mg/l, Vizeletüledék: ismétel-

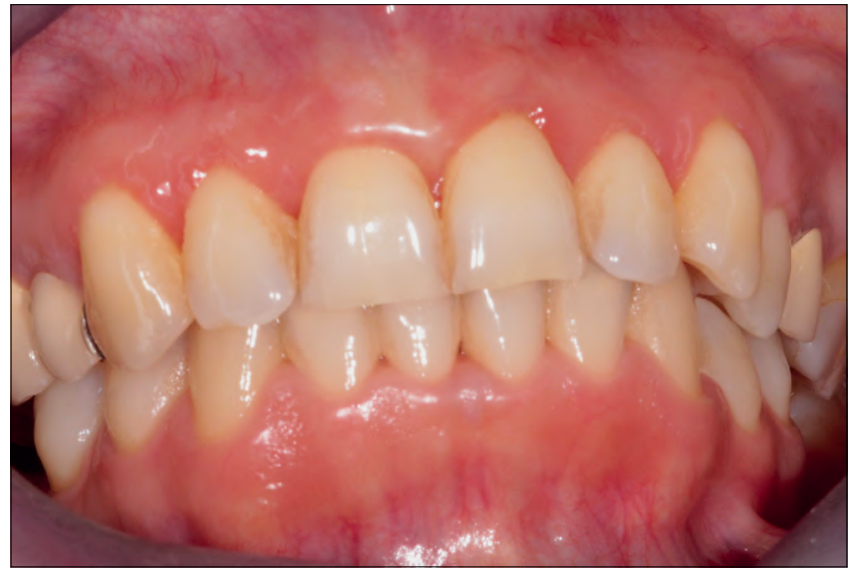

ten 25-30 vvt. 24 órás vizelet fehérje: $252 \mathrm{mg}$ (norm. 0-120) Vér Quantiferon TB teszt: negatív.

Az immunológiai laboratóriumi vizsgálat ANCA szúrőteszt, IIF: c-ANCA erősen poz. 1:40 és az Anti-Proteináz-3 at. EIA/CIA $416 \mathrm{U}$ (norm. O-20). Közben a kemény, tömött nyálmirigyből tübiopsziás mintavétel is történt. A mindkét oldali megnagyobbodott inhomogén echoszegény submandibularis nyálmirigyből vett ultrahangvezérelt vékonytü biopsziás anyag HE citológia lelet nagy mennyiségű granulomatózus histiociter sejtcsoportokat, több többmagvú histiociter óriássejtet és nagyszámú PMN leukocitát mutatott ki. A vizsgálat nekrotizáló granulomatózus gyulladást mutatott ki (12. ábra $a, b$ ), amely a c-ANKA pozitív lelet birtokában megerősítette a Wegener granulomatózis diagnózisát.

A most már biztos diagnózis birtokában megkezdődött a beteg lege artis immunszuppresszív kezelése (80 mg Sulo-Medrol iv, Pantopropazole $2 \times 20 \mathrm{mg}$ ). A terápia ellenére a hospitalizáció első hetében (január 2026.) általános állapota tovább romlott, a folyamat még inkább generalizálódott, egyre súlyosbodó pulmonális tünetei voltak, és a többször megismételt pulmonológiai képalkotó vizsgálatok eredménye és a pulmonológiai kon-

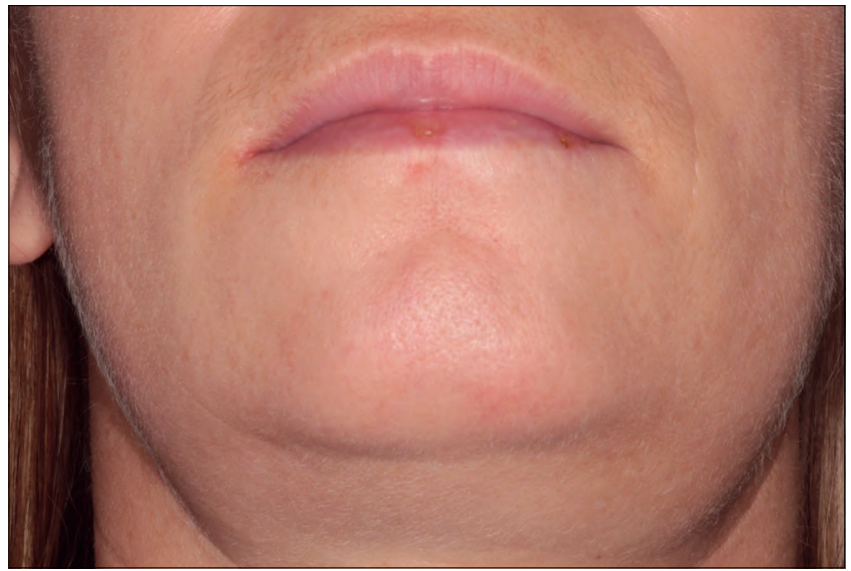

11. ábra a) Az gingiva állapota január 10-én, b) ugyanakkor súlyos kétoldali submandibuláris kemény duzzanat fejlődött ki.
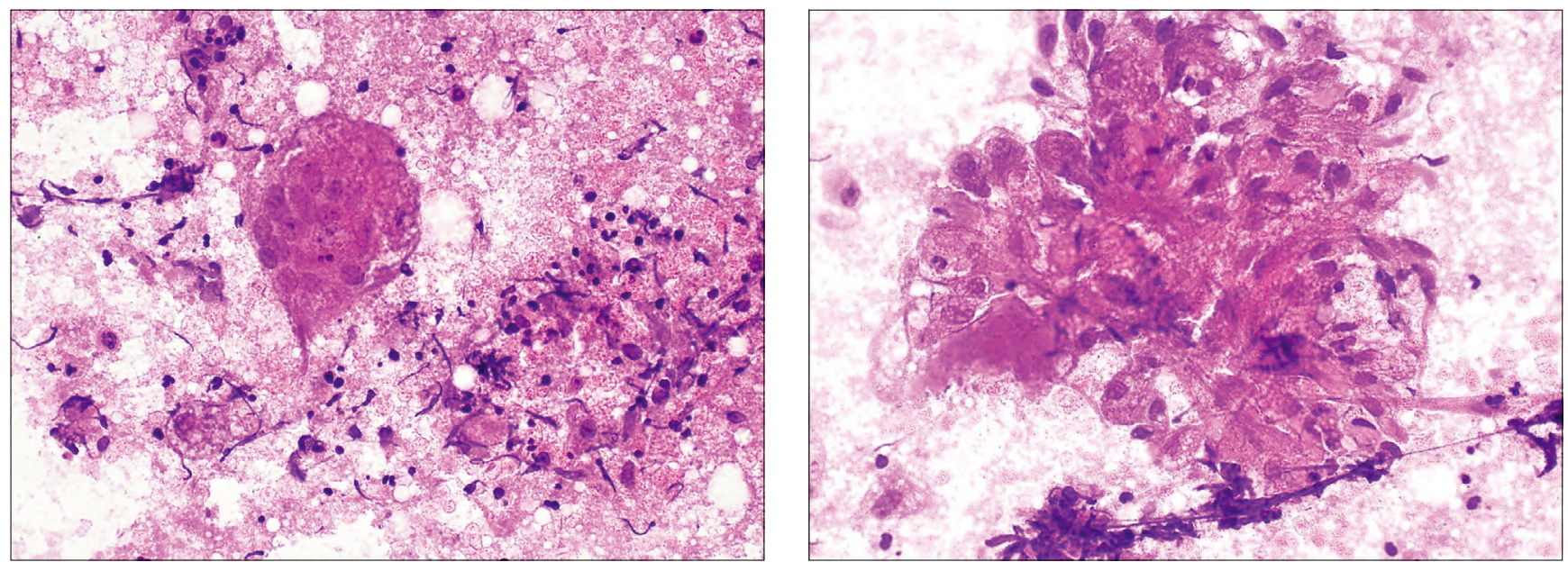

12. ábra a), b) A submandibuláris nyálmirigyből vett ultrahang-vezérelt vékonytű biopsziás anyag hisztológiai vizsgálat necrotizáló granulomatózus gyulladást mutatott ki, amely megerősítette GPA diagnózisát. 
zílium is megerősítette a GPA diagnózist. A mellkasi röntgenfelvétel szerint dorsalisan a 6-os segmentumban bal oldalon a hílus alsó pólusa alatt egy $\mathrm{kb} .5 \mathrm{~cm}$ átmérőjü, jobb oldalon craniálisabban és ventrálisabban egy kb. 4,7 $\times 3 \mathrm{~cm}$-es gyürüárnyék figyelhető meg. A CT- vizsgálat bal oldalon dorsobasalisan egy kb. $58 \times$ $40 \mathrm{~mm}$-es, vaskos fallal körülvett, cavitálódó képletet azonosított. Jobb oldalon parahilárisan egy $33 \times 28 \mathrm{~mm}$ es hasonló képlet volt azonosítható. Mindkét oldalon elszórtan további néhány cavitálódó képlet látható 6$15 \mathrm{~mm}$ átmérővel. Radiológiai diagnózis: a látott kép Wegener granulomatosisnak megfelelhet. (13. ábra $a, b)$.

$\mathrm{Az}$ alsó végtagi keringési elégtelenségre mutató alsó végtagi fájdalom és a lábujjak livid elszíneződése miatt páciensünk a SE Kardiológiai Központ Érsebészeti osztályára került. A hospitalizáció 10. napján a bal talpán zsibbadásérzésre panaszkodott, és a bal nagy lábujj körmétől laterálisan foltozott lividitás jelent meg. Fizikális vizsgálat során a bal oldali artéria dorsalis pedisben (ADP) és az artéria tibialis anteriorban (ATP) pulzáció nem volt tapintható. Az elvégzett lézer doppler és angiográfiás vizsgálatok jelentős érelzáródást mutattak ki a bal oldali lábszárban. A Doppler-vizsgálat eredménye: RR: 100/60 Hgmm, jobb oldali: 80, ATP: 80, bal oldali ADP: nem detektálható, bal oldali ATP: nem detektálható. Kapillármikroszkópia eredménye: a kapilláris vérteltség alacsony, több kóros morfológiájú, gomolyagszerű kapilláris látható. Az elvégzett angiográfiás vizsgálat eredménye: az aorta bifurkáció és az artéria poplitea oszlás között ép érrendszer ábrázolódott meglassult áramlással. A panaszosabb bal oldalon a. peronea követhető a lábszár középső harmadáig, itt azonban elzáródott. Ettől distalisan csak gyér kollaterálisok telődnek. A másik két ér teljesen elzáródott. Sem az a. dorsalis pedis, sem a talpi artériák nem telődnek. Jobb oldalon az a. tibialis anterior és a peronea telödik, a posterior elzáródott. A bal arteria brachialis lumene megtartott. $A z$ a. radialis és a. ulnaris telődése megtartott, a tenyéri ív átjárható. Az érsebész a mütéti vagy egyéb invazív intervenciós beavatkozásra nem látott esélyt. Terápiás dózisú LMWH (heparin), napi $100 \mathrm{mg}$ ASA, 21 napos, napi 20 mikrogrammos Alprestil infúziós kúra javasolt. Néhány nap alatt a Wegener granulomatózisra szintén jellemző nyeregorr alakult ki (14. ábra).

Az agresszív immunszuppresszív terápia és az alsó végtag keringését javító gyógyszeres kezelés hatására állapota fokozatosan javult. A február közepén elvégzett mellkasi röntgen kontrollfelvétel szerint a tüdőstátusz javult. Jobb oldalon dorsalisan már csak kb. $36 \mathrm{~mm}$-es vékony falú gyưrúárnyék, bal oldalon a hílus alsó pólusánál kb. $30 \mathrm{~mm}-\mathrm{es}$, szintén vékony falú gyürüárnyék volt látható (15. ábra). Hasonlóan javultak az alsó végtagok keringési paraméterei is. A február végén elvégzett lézerdoppler vizsgálat szerint a jobb lábban a keringés teljesen helyreállt, a bal lábban jelentős javulást mutatott. Elbocsátáskor a kétoldali submandibuláris nyálmirigyduzzanat spontán remisszióba ment át és már nem volt tapintható. A páciens 2017. február 24-én hagy-
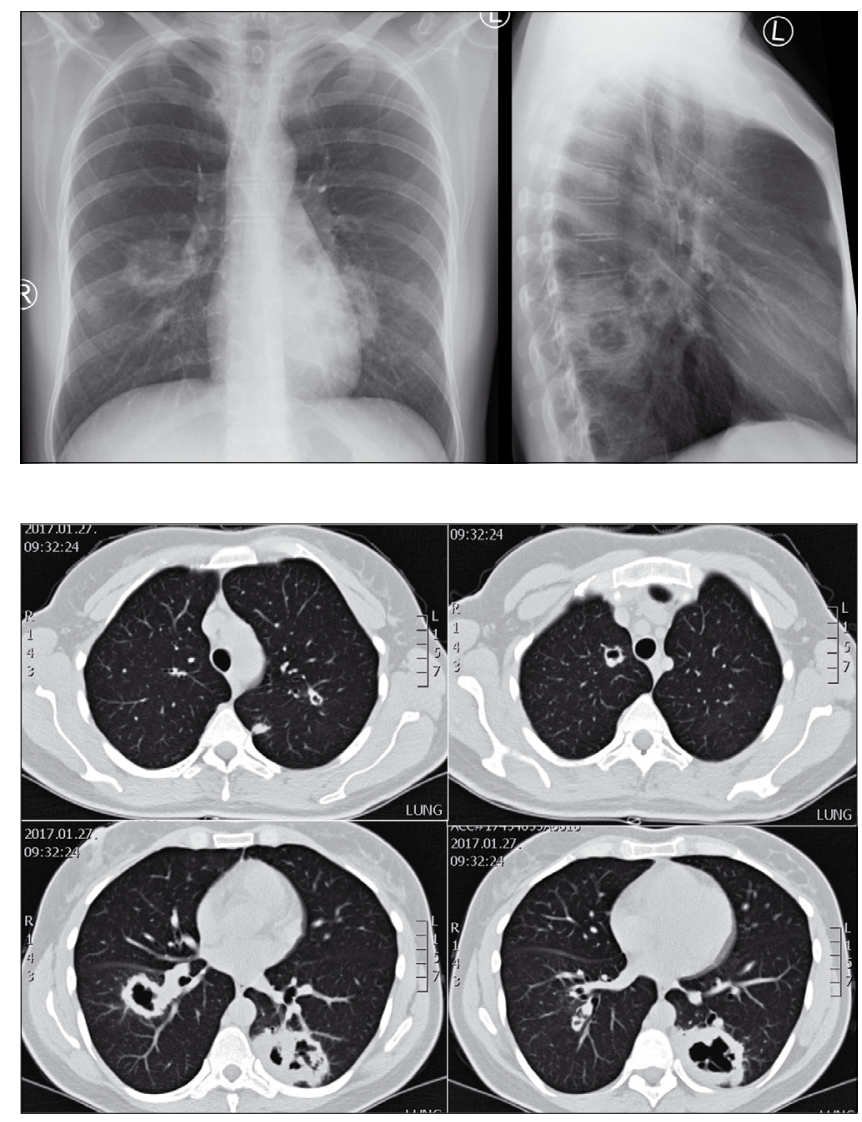

13. ábra a), b) pulmonológiai képalkotó vizsgálatok eredménye: a) A mellkasi röntgenfelvétel: dorsalisan a 6-os segmentumban bal oldalon a hílus alsó pólusa alatt egy kb. $5 \mathrm{~cm}$ átmérőjü, jobb oldalon cranialisabban és ventrálisabban

egy kb. 4,7 ×3 cm-es gyürúárnyék figyelhető meg. b) A CT-vizsgálat: Bal oldalon dorsobasalisan

egy kb. $58 \times 40$ mm-es, vaskos fallal körülvett, cavitálódó képlet azonosított. Jobb oldalon parahilarisan egy $33 \times 28 \mathrm{~mm}$-es hasonló képlet volt azonosítható.

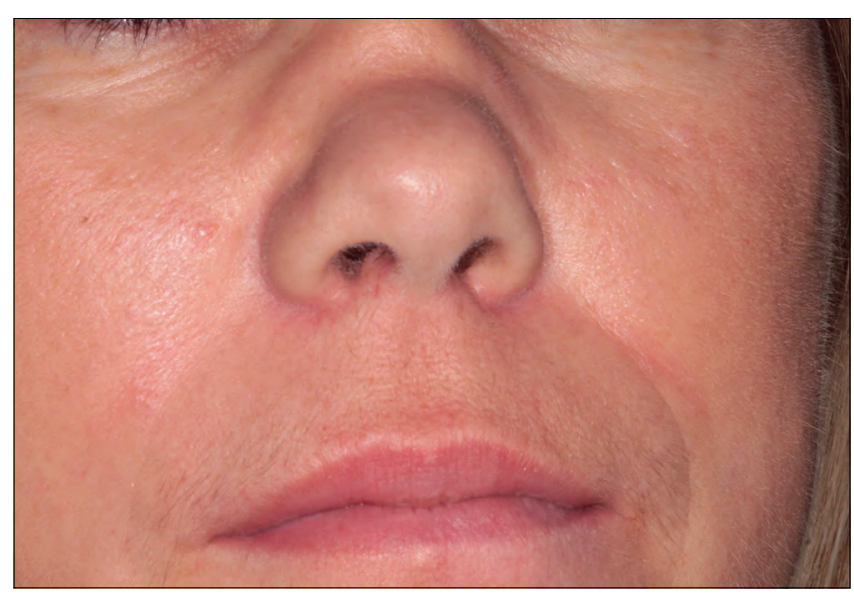

14. ábra: január végére néhány nap alatt

a Wegener granulomatózisra szintén jellemző nyeregorr alakult ki.

ta el a kórházi ágyat. Otthonában a következő fenntartó gyógyszeres kezelésben részesül: napi $32 \mathrm{mg}$ Medrol, $2 \times 100 \mathrm{mg}$ Noclaud, $100 \mathrm{mg}$ Aspirin protect, 


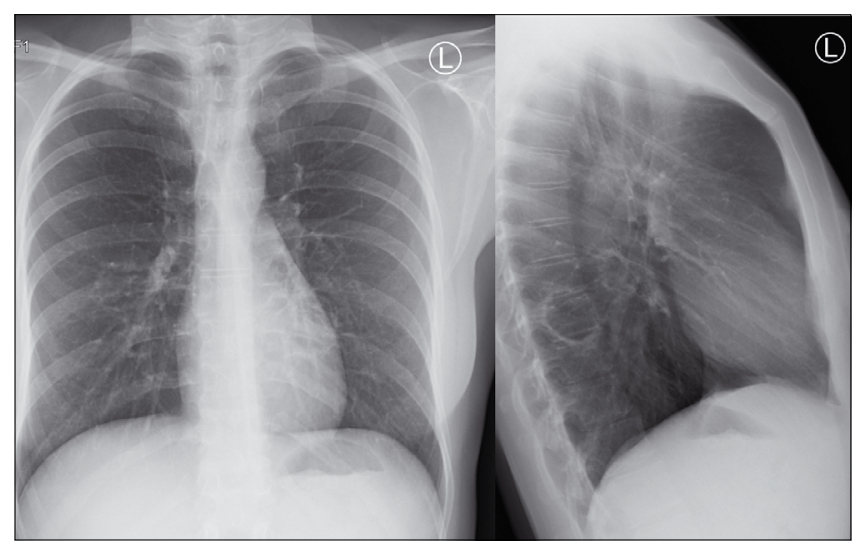

15. ábra: A február közepén elvégzett röntgenkontroll eredménye szerint a tüdőstatus javult. Jobb oldalon dorsalisan kb. $36 \mathrm{~mm}$-es vékony falú gyűrűárnyék van. Bal oldalon a hílus alsó pólusánál

kb. 30 mm-es, szintén vékony falú gyürüárnyék látható.

2 mg Syncumar mite, reggel 2,5 mg Concor és $2 \times 40 \mathrm{mg}$ Pantoprazol. A cyclophsophamid kezelés havonta egy alkalommal folyik tovább. A páciens március 14-én jelent meg parodontális kontrollvizsgálaton. Orális állapota kielégítő, a gingiva teljesen ép, a nyaki és submandibularis fizikális tapintási lelete negatív. Az egyedüli maxillofaciális eltérést a jelentős mértékben besüppedt orrnyereg jelenti, amelynek későbbi plasztikai korrekciója szóba jöhet (16. ábra a, b). Egyébként a páciens fájdalmai megszúntek, járása jó, kedélyállapota vidám és bizakodó. Úgy tűnik, hogy a négyhónapos, nagyon súlyos és kritikus betegség nyugvópontra került, azonban páciensünk legalább kétéves utókezelésre és tartós fenntartó gyógyszeres kezelésre szorul, és a remisszió veszélye bármikor fennáll.

\section{Megbeszélés}

Antineutrophil cytoplasmic autoantibodies (ANCAs) az oka, de legalábbis társul számos különböző típusú vasculitisszel, amely számos szervet érinthet. Bár a primer „target organ” a leukociták antigénjei és ennek révén a kis erek hálózata, azonban az ANCA okozta vasculitis (ANCA-associated vasculitis (AAV) kiterjedhet a nagy erekre, károsíthatja az arteriákat, arteriolákat, vénákat és vénulákat is [18, 48]. Az ANCA-asszociált vasculitis extravaszkuláris károsodásokat okoz, amely leggyakrabban a felső vagy alsó légutakat érinti, valamint a vesét, a bőrt és a periférikus idegrendszert. A vasculitisben szenvedő páciensek esetében a két legjobban dokumentált autoantigén a PMN leukocita mieloperoxidáz (MPO) és a proteináz 3 (PR3). A kifejlődése időpontjában az AAV korlátozódhat csak egy szervre (pl. tüdő vagy vesekárosodás) de lehet sokkal kiterjedtebb, generalizált forma is. Esetünkben olyan generalizált formával találkoztunk, amely a szájüregben a gingiva gyulladásával kezdődött és végighaladt az egész szervezeten a veséket kivéve, érintve a legtöbb klasszikus
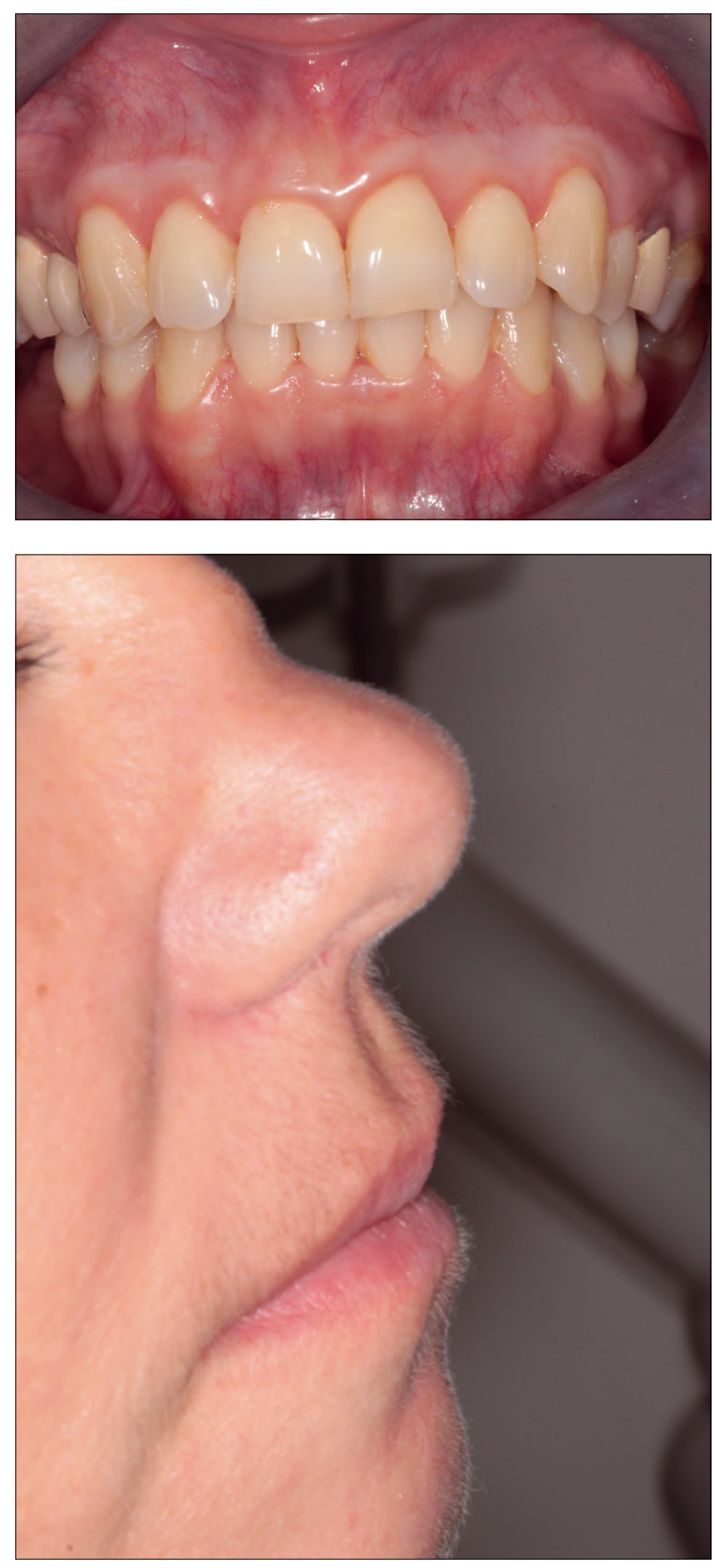

16. ábra a), b) A páciens emittálásakor a submandibuláris nyálmirigy duzzanat spontán visszafejlődött, az íny állapota stabil volt,

azonban az orr deformitása (nyeregorr) még tovább romlott.

target szövetet (orrmelléküreg, nyálmirigyek, tüdő, idegrendszer). Bár a GPA elsősorban a kis erek autoimmun betegsége, de esetünkben jelentősen károsodott több nagy artéria is, veszélyeztetve a végtagok teljes vérellátását. Az a. tibialis anterior, a. dorsalis pedis obliterációja következtében gyakorlatilag a bal alsó lábszár keringése teljesen leállt, a jobb jelentősen korlátozódott. 
GPA betegségben a nagy erek érintettsége igen ritka, csak elvétve találkozhatunk az irodalomban olyan esettanulmányokkal, ahol a mi esetünkhöz hasonlóan Wegener granulomatosis végtaggangrénával társult [3, 22, 28, 30].

Esetünkben a GPA rapid módon kifejlődő, kezdetben fájdalmatlan ínyhiperpláziával kezdődött, amelyet lépésről lépésre követtek az egyre súlyosbodó általános tünetek és más szervek érintettsége. A Wegener granulomatosis irodalmában csak néhány közlemény számol be az ún. „strawberry gingivitisről”, mint az immunvasculitis egyik iniciális jellegzetes orális tünetéről. Eddig összesen 10-12 olyan esetről olvashattunk a nemzetközi irodalomban, ahol az ínyhiperplázia (strawberry gingivitis) az immun vasculitis egyik legelső tünete volt [2, 6 , 14, 47, 52]. Egy közleményben olyan esetről számoltak be, ahol egy hat éve WG miatt kezelt, tartós kortikoszteroid fenntartó kezelés alatt álló betegben a folyamat fellángolásával párhuzamosan fejlődött ki a „strawberry gingivitis” [23]. Egy negyven WG esetet feldolgozó közleményben két esetben találtak orális tüneteket és kettőben fordult elő orális és bőr lézió, ebből egy esetben fordult elő gingivahiperplázia [43]. Csiszér és munkatársai 30 évet felölelő statisztikájában a 15 esetből egyik betegnek sem volt orális elváltozása [10].

Minden szerző kiemeli a korai diagnózis és az időben megkezdett adekvát immunszuppresszív kezelés fontosságát. Jelen esetünkben, miután az azonnal elvégzett hematológiai vizsgálatok kizárták a leukémia gyanúját, okulva előző esetünkön és a nagyfokú klinikai hasonlóságon, a betegünknek napi $2 \times 32$ mg Medrolt rendeltünk. Ezt a beteg egyik immunológus orvosa leállította, arra hivatkozva, hogy nem kizárható a mikrobiális infekció. Ezt igazolni látszott a később kapott immunvirológiai lelet is, miszerint a december elején elvégzett szerovirológiai vizsgálatok igen magas anti-citomegalovírus CMV és anti-Epstein-Barr vírus EBV ellenanyag titert mutattak ki betegünkben, amely valószínúsítette a mononucleosis infectiosa diagnózisát [13]. A különleges ínyduzzanatot leszámítva a páciens összes jellemző tünete elvileg mind megfelelhettek a súlyos mononucleoisis infectiosa tüneteinek (nagyon fájdalmas torokgyulladás, cervicalis limfadenopátia, láz, elesettség, abdominális fájdalom, nausea, orális petechiák, periorbitalis ödéma, és bőrpír [13]. Sajnálatos módon ez a szerovirológiai lelet elterelte a figyelmet az elsőnek feltételezett autoimmun folyamatról, és ezzel sajnálatos módon adekvát terápia hiányában a betegsége december-január fordulóján tovább súlyosbodott és generalizálódott. 2017 januárjában tüdőgyulladást diagnosztizáltak betegünknél, és a submandibuláris és sublingualis nyálmirigyduzzanat olyan mértéket ért el, hogy ez már táplálkozási nehézséget okozott. $A$ beteg olyan gyenge volt, hogy már járni sem volt képes. Ekkor került betegünk a III. Belgyógyászati Klinika Immunológiai Osztályára, ahol kimutatták a c-ANCA jelenlétét és az elvégzett nyálmirigy tűbiopszia is alátámasztotta a Wegener granulomatozis dignózisát. A hospitalizáció első hetében megkezdett szteroid (130 mg/nap) és cyclophosphamid kezelés ellenére alakult ki az alsó végtag ereiben a súlyos obliteráló vasculitis, amely csak nagyon határozott és célzott immunszuppreszív és vazodilatációs kezeléssel lassan helyreállította az alsó végtagok keringését, és végül ez mentette meg a fiatal asszony lábait. Csak napokon múlott, hogy nem került sor amputációra. Február végére a beteg állapota lassan rendeződött, március elején állapota rohamosan javult, spontán gyógyult a nyálmirigyduzzanat és jelentősen javult a pulmonális állapot is. Fájdalmai megszüntek, azonban a Wegener granulomatozisra jellemző késői tünet, a „nyereg orr” képe megmaradt (16. ábra). Ennek plasztikai korrekciója szóba jöhet az általános tünetek stabilizálódása után [15].

Tanulságul kell megjegyezni, hogy mindkét biopsziás lelet eredménye nem specifikus piogén granulóma volt a szövettanász szerint. Irodalmi adatok is alátámasztják, hogy a bőrből vagy gingivából vett szövettani minta diagnosztikus értéke csekély, mivel a felszínes szövetekben zajló gyulladásos jelek elfedik az immun vasculitis jellegzetes szövettani képét [18, 42]. Esetünkben a nyálmirigy-biopszia volt diagnosztikus értékü, amely a pozitív c-ANCA lelet birtokában megerősítette a Wegener granulomatózist. Sajnálatos módon az iniciális „strawberry gingivitis" megjelenése után több mint két hónapnak kellett eltelnie, amíg a pontos diagnózis megszületett és a beteg adekvát immunszuppresszív kezelésben részesülhetett, annak ellenére, hogy nagyon sok immunológus, hematológus és infektológus látta ez idő alatt. A páciens általános állapotának stabilizálódásával teljeskörü fogászati szanálásra szorul, terveink szerint a 28 fog extrakciója, több gyökértömés revíziója lesz szükséges.

\section{Irodalom}

1. BAJEMA IM: Pathological classification of anti-neutrophil cytoplasmic antibody (ANCA)-associated glomerulonephritis. Clin Exp Immunol 2011; 164 (1): 14-16.

2. BHATT V, HALL TJ: Strawberry gingival enlargement as only manifestation of Wegener's granulomatosis. Br J Oral Maxillofac Surg 2009; 47: 500 .

3. BINDER $C$ et al: Severe toe gangrene as an early manifestation of Wegener granulomatosis in a young patient Z. Rheumatol 1998; 57: 227-230.

4. Calne RY: Cyclosporin-A in clinical organ grafting. Transpl Proc 1981; 13: 349-358.

5. Carrington CB, Liebow AA: Limited forms of angiitis and granulomatosis of Wegener's type. Amer J Med 1966; 41: 497-527.

6. Cohen RE, Cardoza TT, Drinnan AJ, Aquirre A, Neiders ME: Gingival manifestations of Wegener's granulomatosis. J Periodontol 1990; 61: 705-709.

7. CoOper CL, Loewen R, Shore T: Gingival hyperplasia complicating acute myelomonocytic leukemia. J Can Dent Assoc 2000; 66: 78-79.

8. Cornec D, Cornec-Le Gall E, Specks U: Clinical trials in antineutrophil cytoplasmic antibody-associated vasculitis: what we have learnt so far, and what we still have to learn. Nephrol Dial Transplant 2017; 32: 37-47.

9. Csifó-Nagy B, Hulik E, Zsoldos GM, Gera I: Extrém méretű iatro- 
gén eredetú ínyhiperpláziák sebészi korrekciója (esetsorozat). Fogorvosi Szemle. 2013; 106: 61-70.

10. Csiszér E, Soltész I, Füzesı K: Wegener-granulomatosis - Diagnosztikai kérdések 15 beteg kapcsán. LAM 2001; 11 (8-9): 566-572.

11. Demirer S, Ozdemir H, Sencan M, Marakoglu I: Gingival hyperplasia as an early diagnostic oral manifestation in acute monocytic leukemia: a case report. Eur J Dent 2007; 1: 111-114.

12. Dreizen S, Mccredie KB, Keating MJ, Luna MA: Malignant gingival and skin „infiltrates” in adult leukemia. Oral Surg Oral Med Ora Pathol 1983; 55: 572-579.

13. Dunmire SK, Hogquist KKA, Balfour HH: Infectious Mononucleosis. Curr Top Microbiol Immunol 2015; 390: 211-240.

14. Eufinger H, Machtens E, Akuamoa-Boateng E: Oral manifestations of Wegener's granulomatosis. Review of the literature and report of a case. Int J Oral Maxillofac Surg 1992; 21: 50-53.

15. Ezzat WH, Compton RA, Basa KC, LeVI J: Reconstructive Techniques for the Saddle Nose Deformity in Granulomatosis With Polyangiitis: A Systematic Review. JAMA Otolaryngol Head Neck Surg 2016 Dec 15.

16. Ferri E, Armato E, Capuzzo P, Cavaleri S, Ianniello F: Early diagnosis of Wegener's granulomatosis presenting with bilateral facial paralysis and bilateral serous otitis media. Auris Nasus Larynx 2007; 34 (3): 379-382.

17. Fujimoto S, Watts RA, Kobayashi S, Suzuki K, Jayne DR, Scott $D G$, et al: Comparison of the epidemiology of anti-neutrophil cytoplasmic antibody-associated vasculitis between Japan and the U. K. Rheumatology (Oxford, England) 2011; 50 (10): 1916-1920.

18. Gadó K, Z Szabó L, Csákó L, Domján Gy: Wegener-granulomatosis. Orv. Hetil 2013; 154: 1083-1095.

19. Gera I és mtsai: Parodontológia tankönyv, Semmelweis Kiadó 2009; 5. fejezet: 79-111. 7. fejezet: 158-161. 12. fejezet: 335336. 13. fejezet 302. oldal.

20. Gillette WB: Oral manifestations of acute myelomonocytic leukemia: a case report and review of the classification of leukemias. Wu J, Fantasia Je, Kaplan R. J Periodontol 2002; 73: 664-668.

21. Guillevin L, Girard T, Mahr A, Noël LH, Cordier JF, Lesavre $P$, ANDRÉ MH: Are antineutrophil cytoplasmic antibodies a marker predictive of relapse in Wegener's granulomatosis? A prospective study. Rheumatology (Oxford, England) 2001; 40: 147-151.

22. HANDA $R$, et al: Wegener's granulomatosis with gangrene of toes Scand. J. Rheumatol 1996; 25: 103-104.

23. HANISCH M, FRÖHLICH LF, KLEINHEINZ J: Gingival hyperplasia as firs sign of recurrence of granulomatosis with polyangiitis (Wegener's granulomatosis): case report and review of the literature. BMC Oral Health 2016; 17: 33-37.

24. Hernández G, Serrano C, Porras L, Lopez-Pintor R, Rubio L, YANES J: Strawberry-like gingival tumor as the first clinical sign of Wegener's granulomatosis. J Periodontol 2008; 79: 1297-1303.

25. Horning GM, Fischer JG, Barker F, Killoy WJ, Lowe JW: Gingival fibromatosis with hypertrichosis. J Periodontol 1985; 56: 344-347.

26. Jennette JC, Falk RJ, Gasim AH: Pathogenesis of antineutrophil cytoplasmic autoantibody vasculitis. Curr Opin Nephrol Hypertens 2011; 20: 263-270.

27. Kallenberg CG: Pathogenesis of ANCA-associated vasculitis, an update. Clin Rev Allergy Immunol 2011; 41: 224-231.

28. KARJALAINEN $A$, et al: Still another case of Wegener's granulomatosis with digital gangrene Scand. J Rheumatol 1996; 25: 339-342.

29. Keglevich T, Benedek E, Gera I: A kálciumcsatorna-blokkolók okozta ínyhyperplasia. Lege Artis Med 1999; 9: 164-168.

30. LA CIVITA L et al: Wegener's granulomatosis of the elderly: a case report of uncommon severe gangrene of the feet. Ann Rheum Dis 1995; 54: 328.

31. Lederman D, Lumerman H, Reuben S, Freadman PD: Gingival hyperplasia associated with nifedipin therapy. Oral Surg 1984; 54 : 620-622.

32. Leon G. Clark, BAA, Stanislav N. Tolkachuov, mDB, Alina G Bridges, Dob, C, MiChaEL J. camilleri, mdb: Pyostomatitis vegetans
(PSV)-pyodermatitis vegetans (PDV): A clinicopathologic study of 7 cases at a tertiary referral center. J Am Acad Dermatol 2016; 75: 578-584.

33. LiLly J, JuHLin T, LeW D, Vincent D, LiLLy G: Wegener's granulomatosis presenting oral lesions. A case report. Oral Surg Oral Med Oral Pathol 1998; 85: 153-157.

34. Lundgren D, Magnunssen B, Lindhe J: Connective tissue alterations in gingiva of rats treated with oestrogens and progesteron. Odontological Rev 1973; 24: 49-58.

35. Manchanda Y, Tejasvi T, Handa R, Ramam M: Strawberry gingiva: a distinctive sign in Wegener's granulomatosis. J Am Acad Dermatol 2003; 49: 335-337.

36. Mohammad AJ, Jacobsson LT, Westman KW, Sturfelt G, SegelMARK M: Incidence and survival rates in Wegener's granulomatosis, microscopic polyangiitis, Churg-Strauss syndrome and polyarteritis nodosa. Rheumatology (Oxford, England) 2009; 48: 1560-1565.

37. Moosig, F, Lamprecht $P$, Gross WL: Wegener's granulomatosis: the current view. Clin Rev Allergy Immunol 2008; 35: 19-21.

38. Nakamura $S$, Hiroki $A$, Shinohara $M$, et al: Oral involvement in chronic graft-versus-host disease after allogeneic bone marrow transplantation. Oral Surg Oral Med Oral Pathol Oral Radiol Endod 1996; 82: 556-563.

39. Napier SS, Allen JA, IRWin CR, Mccluskey DR: 'Strawberry gums' - a case of Wegener's granulomatosis. Br Dent J 1993; 175: 327-329.

40. Nishikawa S, Toda H, Hamasaki A, Kasahora $S$, et al: Nifedipineinduced gingival hyperplasia: a clinical and in vitro study. J Periodontol 1991; 62: 30.

41. Noce CW, Gomes A, Copello A, Barbosa RD, et al. Oral involvement of chronic graft-versus-host disease in hematopoietic stem cell transplant recipients. Gen Dent 2011; 59: 458-462.

42. PAGNoux C: Updates in ANCA-associated vasculitis. Eur J Rheumatol 2016; 3: 122-133.

43. PATTEN SF, TOMECKI KJ: Wegener's granulomatosis: cutaneous and oral mucosal disease. J Am Acad Dermatol 1993; 28: 710-718.

44. PHILIPS RW, et al: Wegener's granulomatosis and gangrene in the feet. Ann Intern Med 1983; 99: 571-575.

45. Reumaux D, Duthilleul P, Roos D: Pathogenesis of diseases associated with antineutrophil cytoplasm autoantibodies. Hum Immunol 2004; 65: 1-12. Rostock MH, FRY HR, TURNER JE: Severe gingival overgrowth associated with cyclosporin therapy. J Periodontol 1986; 57: 294-299.

46. Ruokonen H, Helve T, Arola J, Hietanen J, Lindqvist C, Hogstrom J: „Strawberry gingivitis" being the first sign of Wegener's granulomatosis. Eur J Int Med 2009; 20: 651-653.

47. Savige J, Davies D, Falk RJ, Jennette JC, Wilk A: „Antineutrophil cytoplasmic antibodies and associated diseases: a review of the clinical and laboratory features". Kidney International 2000; 57: 846-862.

48. Sepúlveda E, Brethauer U, Fernández E, Cortés G, Mardones C: Oral manifestations as first clinical sign of acute myeloid leukemia: report of a case. Pediatr Dent 2012; 34: 418-421.

49. Shiboski CH, Regezi JA, Sanchez HC, Silverman S JR: Oral lesions as the first clinical sign of microscopic polyangiitis: a case report. Oral Surg Oral Med Oral Pathol Oral Radiol Endod 2002; 94: 707-711.

50. Siar CH, Yeo KB, Nakano K, Nagatsuka $H$, Tsujigina $H$, Tomida M, $\mathrm{NG} \mathrm{KH,} \mathrm{KaWAKAmI} \mathrm{T:} \mathrm{Strawberry} \mathrm{gingivitis} \mathrm{as} \mathrm{the} \mathrm{first} \mathrm{presenting}$ sign of Wegener's granulomatosis: report of a case. Eur J Med Res. 2011; 16: 331-334.

51. Steward C, Cohen D, Bhattacharyya I, Scheitler L, Riley S, Calamia K, Migliorati C, Baughman R, Langford P, Katz J: Oral manifestations of Wegener's granulomatosis: a report of three cases and a literature review. J Am Dent Assoc 2007; 138: 338-348.

52. Watts RA, Mooney J, Skinner J, Scott DG, Macgregor AJ: The contrasting epidemiology of granulomatosis with polyangiitis (Wegener's) and microscopic polyangiitis. Rheumatology (Oxford, England) 2012; 51: 926-931. 
53. WEGENER F: Über generalisierte, septische Gefasserkrankungen Verh Dtsch Pathol Ges 1936; 29: 202-209.

54. WEGENER F: Über eine eigenartige rhinogene Granulomatose mit besonderen Beteiligung des Arteriensystems und der Nieren. Beitr Path Anat 1939; 102: 36-38.
55. Wu J, Fantasia JE, KaPLAN R: Oral manifestations of acute myelomonocytic leukemia: a case report and review of the classification of leukemias. J Periodontol 2002; 73: 664-668.

Gera I, Bognár VL, KRIstóf V, Istók R, JaKaB L

\section{A rare case of (Strawberry Gingivitis) associated with Wegener granulomatosis (Granulomatosis with polyangiitis GPA) \\ Review of the literature and case presentation}

Rapidly developing gingival hyperplasia is always an alarming periodontal condition because of being the first clinical sign of several malignant hematological diseases: notably acute myeloid, monocyter and lymphoid leukemia. This paper describes a 35-year-old female patient's case who presented the typical form of the so called "strawberry gingivitis" that developed within two days in mid October 2016. After several detailed medical and immunological examinations the possibility of any malignant hematological diseases was excluded and therefore conventional gingivectomy was performed under local anaesthesia. The total excised tissue was sent to histology. The histology resulted in the diagnosis of a nonspecific pyogenic granuloma. After gingivectomia the gingival healing was very uneventful leading to total re-epithelialization of the gum in three weeks, and no recurrence occurred afterwards. Nevertheless, patient's general physical condition further deteriorated and more and more organs were involved in the process. After several additional blood tests, immunological examinations and a positive test for EBV-infection a tentative diagnosis of infective mononucleosis was set up that lead to several weeks of delay in the indication of appropriate therapy. Finally, in mid January it was diagnosed as GPA (Wegener's granulomatosis) on the basis of the plethora of characteristic clinical symptoms (strawberry gingivitis, sinus and ear infection, saddle nose, pneumonia and salivary gland swelling) but finally verified by the presence of the anti-neutrophil cytoplasmic antibody (c-ANCA test) and a positive biopsy from the submandibular salivary gland. Then the patient in very serious physical condition was admitted to the Clinic of Internal Medicine, Semmelweis University and subsequently placed on a massive corticosteroid and immunosuppressive regiments of therapy. The GPA showed an unusual generalization pattern affecting practically all tissues and also the major blood vessel in the lover extremities, leading to the halt of circulation. Due to an effective immuno-suppressive therapy combined with vasodilatation patient's general physical condition improved, the circulation was restored in her legs, the pulmonary involvement improved and the salivary gland hyperplasia receded.

The early diagnosis is crucial in this potentially fatal disease to apply an adequate therapy and control the rapid progression and the generalization of disease. In our case there have been several weeks of delay because of the non specific histological results from the gingival biopsy and the very high circulating anti-EBV and CMV antibody titer, that predicted the possibility of infectious mononucleosis. Because of GPA's rapid progression and potentially fatal outcome, an early diagnosis of GPA is vital and very important. Therefore, dentists should be aware of the oral signs, notably the very rare but very characteristic strawberry gingivitis and the complex symptoms of such systemic immune vasculitis. This case report shows that the gingival hyperplasia may represent an initial manifestation of an underlying systemic disease and if it properly recognized can accelerate the final diagnosis and the administration of proper therapy.

Keywords: gingival hyperplasia, Wegener's granulomatosis, Granulomatosis with Polyangiitis, the anti-neutrophil cytoplasmic antibody 